\title{
Presoaking Treatment of Propolis Aqueous Extract Alleviates Salinity Stress in Spinach (Spinacia oleracea L.) Plants Grown under Calcareous Saline Soil Conditions
}

\author{
Mohamed A. Seif El-Yazal \\ Botany Department, Faculty of Agriculture, Fayoum University, Fayoum 63514, Egypt \\ mas04@fayoum.edu.eg
}

Keywords: spinach plants (Spinacia oleracea L.), propolis extract, salinity, growth, yield, chlorophyll, carotenoids, anthocyanin, carbohydrates, sugars, free amino acid, indoles, phenols, proline.

\begin{abstract}
Two pot experiments were conducted during the two successive seasons of 2014 and 2015 to study the effect of propolis extract at the rates $0,6000,7000,8000$ and $9000 \mathrm{mg} / \mathrm{L}$ solution used as seed soaking to spinach seedlings on growth, yield and some chemical constituents of spinach plants (Spinacia oleracea L.) grown under calcareous saline soil conditions. The obtained results indicated that increasing the rates of propolis extract as seed soaking application increased the growth parameters of the treated plants. The best result was obtained by the middle rate $(7000 \mathrm{mg} / \mathrm{L})$ as seed soaking in both seasons of the study. The same trend was also observed regarding all studied chemical constituents, i.e. chlorophyll $\mathrm{a}, \mathrm{b}$ and total caroteniods concentration, anthocyanine, total carbohydrates, total and reducing sugars, total free amino acid, free proline, crude protein, total indoles, total phenols, N, P and K in leaves. Moreover, soaking seeds in propolis extract before planting improved the metabolic activity of seeds through the increase in seed values in total and reducing sugars, total free amino acid, total indoles and total phenols as well as the lowest values of total carbohydrate. Thus, the coincident application of propolis extract at $(7000 \mathrm{mg} / \mathrm{L})$ as a seed soaking ingredient is recommended for improving growth, yield and chemical composition of spinach plants and for overcoming the adverse effect of saline conditions.
\end{abstract}

\section{Introduction}

Spinach could be a common vegetable within the people's everyday life mainly for its characteristic inexperienced color, organic process content like carotenes, vitamin $\mathrm{C}$, and minerals like calcium and iron [1]. The intake of a specific quantity of vegetables will facilitate reducing the risk of many diseases like cancer and vairous disease [2]. Cultivated globally, spinach is additionally a very important raw-material within the food process industry [3]. A general reduction in growth and yield because of salinity is widely documented $[4,5]$ on Spinach plants that, growth and yield of spinach plants were minimized by increasing soil salinity. Many investigators have conducted studies for up salt tolerance of plants [5-7].

In recent years, there is a growing interest with natural bio-stimulating substances. Propolis (bee glue) is the generic name for the pitchy substance collected by honeybees (Apis mellifera L.) and found to be effective against a spread of microorganism, bacteria, viruses and fungi. There are varied literature knowledge of characteristically the chemical composition of propolis [8-13]. Propolis contains many necessary compounds has been detected to have an effect on the activity of many physiological processes in plants $[8,13]$. Amino acids, sugars, bound vitamins (particularly, B-group, C and E), minerals, terpenes and sesquiterpenes are considered or thought-about to be among these necessary compounds. We are aware that terpenes and sesquiterpenes can be significant compounds important to plant growth processes. Terpenoids are thought-about to be the precursors of the many phytohormones (particularly, gibberellins), that are necessary for plants grown under numerous stresses.

The useful impact of propolis extract on growth, yield and chemical constituents of plants was accordingly on several species of plants $[14-16,7,17]$. 
Accordingly, the aim of this work was to check the impact of propolis extract as seed presoaking agent on growth, yield and chemical composition of mature spinach plants under saline conditions of saline calcareous soil and to clarify the role of propolis extract in minimizing the injurious impact of salinity on spinach plants.

\section{Materials and Methods}

The present investigation was conducted during the two successive seasons 2014 and 2015 in the Experimental Station, Faculty of Agriculture, Fayoum University, Egypt. The physical and chemical properties of the soil were tested by the Soil and Water Department, Faculty of Agriculture, Fayoum University using the standard methods described by Klute [18] and Page et al. [19] and are given in Table1.

Table 1. Physical and chemical properties of the soil used before sowing in both seasons

\begin{tabular}{|c|c|c|}
\hline Properties & $\mathbf{2 0 1 4}$ & $\mathbf{2 0 1 5}$ \\
\hline \multicolumn{3}{|c|}{ Physical } \\
\hline Clay\% & 29.30 & 27.50 \\
\hline Silt \% & 20.30 & 21.80 \\
\hline Sand \% & 50.40 & 50.70 \\
\hline Texture grade & Sandy clay loam & Sandy clay loam \\
\hline \multicolumn{3}{|c|}{ Chemical } \\
\hline Organic matter\% & 1.27 & 1.23 \\
\hline $\mathrm{pH}^{-3}$ & 7.77 & 7.79 \\
\hline $\left.\mathrm{EC}(\mathrm{dS} \mathrm{m})^{-1}\right)$ & 7.81 & 7.82 \\
\hline $\mathrm{CaCO} \%$ & 8.50 & 8.49 \\
\hline $\mathrm{N}_{3} \%$ & 0.06 & 0.06 \\
\hline \multicolumn{2}{|c|}{ Available nutrients (mg kg-1 soil) } \\
\hline $\mathrm{P}$ & 19.52 & 19.20 \\
\hline $\mathrm{K}$ & 0.37 & 0.33 \\
\hline $\mathrm{Fe}$ & 5.66 & 5.76 \\
\hline $\mathrm{Mn}$ & 0.79 & 0.80 \\
\hline
\end{tabular}

\section{Preparation of propolis extract (PE)}

Local raw material of propolis was collected from honeybee colonies of the apiary of Faculty of Agriculture, Fayoum Governorate by scraping hives frames and entrances. Collected samples were mixed together and the active ingredients were extracted by ethyl alcohol 95\% [20]. The propolis ethanol mixture was filtered and the alcohol was evaporated under vacuum $\left(30^{\circ} \mathrm{C}\right)$ using rotary evaporator, Buchi model 011 . The extract was kept cool in the refrigerator $\left(4^{\circ} \mathrm{C}\right)$ until use. Propolis extract was diluted by water to give the final concentration required $6000,7000,8000$ and $9000 \mathrm{mg} / \mathrm{L}$ before use. Seed treatments were carried out by soaking spinach seeds in PE or water for $12 \mathrm{hrs}$ before sowing. 
Table 2. Groups of substances identified in the sample of propolis, Based on Walker and Crane [21]

\begin{tabular}{|c|c|c|c|}
\hline Group & $\begin{array}{c}\text { No., } \\
\text { substance }\end{array}$ & Group & No., substance \\
\hline $\begin{array}{l}\text { - Flavonoids } \\
\text { hydroxy flavones } \\
\text { hydroxy flavanones }\end{array}$ & $\begin{array}{l}38 \\
27 \\
11 \\
\end{array}$ & $\begin{array}{l}\text { Terpene and sesquiterpene } \\
\text { alcohols and their derivatives }\end{array}$ & 7 \\
\hline $\begin{array}{l}\text { - Benzoic acid derivatives } \\
\text { acids } \\
\text { esters }\end{array}$ & $\begin{array}{c}12 \\
8 \\
4\end{array}$ & $\begin{array}{l}\text { Sesquiterpene and triterpene } \\
\text { hydrocarbons }\end{array}$ & 11 \\
\hline - Benzaldehyde derivatives & 2 & Aliphatic hydrocarbons & 6 \\
\hline $\begin{array}{l}\text { - Cinnamyl, cinanamic acid } \\
\text { and its derivatives }\end{array}$ & 14 & $\begin{array}{l}\text { Sterols and steroids } \\
\text { hydrocarbons }\end{array}$ & 6 \\
\hline - Other acids and derivatives & 8 & Minerals & 22 \\
\hline $\begin{array}{l}\text { - Alcohols, ketons, phenols } \\
\text { and } \\
\text { compounds }\end{array}$ & 12 & Sugars & 7 \\
\hline Amino acids & 24 & Chalcones & 2 \\
\hline
\end{tabular}

\section{Seed treatment}

Seeds of spinach plants (Spinacia oleracea L.) were obtained from Vegetable Research Institute, Ministry of Agriculture, Egypt. Seeds were sown on $1^{\text {st }}$ November, for both seasons in pots $(30 \mathrm{~cm}$ in diameter and $50 \mathrm{~cm}$ in height) each pot was filled with $20 \mathrm{~kg}$ calcareous saline soil. Spinach seeds were sown in each pot. Two weeks after sowing at complete germination, plants were thinned to two plants /pot.

\section{Pot experimental}

Seeds used in this study were soaking in propolis extract (PE) or water for $12 \mathrm{hrs,} \mathrm{or} \mathrm{unsoaked}$ then grouped under 5 classes as follows:

\section{1-Seeds soaking:}

* Water (12 hrs): Seeds soaking for $12 \mathrm{hrs}$ in water.

* PE $6000 \mathrm{mg} / \mathrm{L}$ (12hrs): Seeds soaking for $12 \mathrm{hrs}$ in propolis $6000 \mathrm{mg} / \mathrm{L}$.

* PE $7000 \mathrm{mg} / \mathrm{L}$ (12hrs): Seeds soaking for $12 \mathrm{hrs}$ in propolis $7000 \mathrm{mg} / \mathrm{L}$.

* PE $8000 \mathrm{mg} / \mathrm{L}$ (12hrs): Seeds soaking for $12 \mathrm{hrs}$ in propolis $8000 \mathrm{mg} / \mathrm{L}$.

* PE $9000 \mathrm{mg} / \mathrm{L}(12 \mathrm{hrs})$ : Seeds soaking for $12 \mathrm{hrs}$ in propolis $9000 \mathrm{mg} / \mathrm{L}$.

After soaking periods, seeds were air dried on filter papers overnight under the room temperature $\left(25^{\circ} \mathrm{C}\right)$ before sowing. Each treatment contains 6 pots. The normal cultural practices for growing spinach plants were applied.

\section{For laboratory study}

Seeds used in this part of the study were treated by propolis extract (PE) and grouped under six classes as follows:

*Untreated seeds: Seeds without soaking in neither water nor PE.

* Water (12 hrs): Seeds soaking for $12 \mathrm{hrs}$ in water.

* PE $6000 \mathrm{mg} / \mathrm{L}$ (12hrs): Seeds soaking for $12 \mathrm{hrs}$ in propolis $6000 \mathrm{mg} / \mathrm{L}$.

* PE $7000 \mathrm{mg} / \mathrm{L}$ (12hrs): Seeds soaking for $12 \mathrm{hrs}$ in propolis $7000 \mathrm{mg} / \mathrm{L}$.

* PE $800 \mathrm{mg} / \mathrm{L}$ (12hrs): Seeds soaking for $12 \mathrm{hrs}$ in propolis $8000 \mathrm{mg} / \mathrm{L}$.

* PE $9000 \mathrm{mg} / \mathrm{L}$ (12hrs): Seeds soaking for $12 \mathrm{hrs}$ in propolis $9000 \mathrm{mg} / \mathrm{L}$.

After soaking period, seeds were air-dried overnight under the room temperature $\left(25^{\circ} \mathrm{C}\right)$. The dried seeds were ground to fine powder for use in the chemical analysis of seeds. 


\section{Fertilization}

All spinach plants including control were fertilized with NPK full recommended dose by the Ministry of Agriculture, Egypt. Phosphorous as triple calcium super phosphate $\left(45-46 \% \mathrm{P}_{2} \mathrm{O}_{5}\right)$ at the rate of $75 \mathrm{~kg} /$ fed., $(1.5 \mathrm{~g} / \mathrm{pot})$ was mixed with soil before sowing. Nitrogen fertilizer was applied in the form of urea $(46 \% \mathrm{~N})$ at the rate of $100 \mathrm{~kg} / \mathrm{fed}$., $(2 \mathrm{~g} / \mathrm{pot})$ and $50 \mathrm{~kg} / \mathrm{fed}$., of potassium sulphate $\left(48 \% \mathrm{~K}_{2} \mathrm{O}\right)(1 \mathrm{~g} / \mathrm{pot})$. The amount of $\mathrm{N}$ and $\mathrm{K}$ fertilizers was divided into two equal doses, the first was added after two weeks from sowing and the second was added at two weeks later.

\section{Measurements}

\section{Growth character}

At harvest time (50-days old plants), samples of each treatment (10 plants) were taken. Plant height $(\mathrm{cm})$, number of leaves/plant, fresh and dry weight of leaves/plant $(\mathrm{g})$ were measured on each plant. Total leaf area $\left(\mathrm{cm}^{2}\right)$ of each plant was estimated by using an area meter, model Li 3000 from LI-COR, USA.

\section{Chemical constituents}

At the age of 50 days (in both seasons) samples of fresh leaves were taken for chemical determination i.e. photosynthetic pigments: chlorophyll a, b and caroteniods were extracted from fresh leaves by acetone (80\%) then, their concentrations were determined (mg/ $100 \mathrm{~g}$ fresh weight) according to [22]. Total carbohydrates $\mathrm{mg} \mathrm{g}^{-1}$ dry weight was determined colorimetrically according to the method described by [23]. Total and reducing sugars were determined according to [24] and recorded as $\mathrm{mg} \mathrm{g}^{-1}$ dry weight. Anthocyanin concentration $\mathrm{mg} / 100 \mathrm{~g}$ dry weight was determined according to the method described by [25]. Total free amino acids in fresh leaves were determined colorimetrically according to the method described by [26] and recorded as $\mathrm{mg} \mathrm{g}^{-1}$ dry weight. Total indoles in fresh leaves were determined colorimetrically according to the method described by [27] and recorded as $\mathrm{mg} \mathrm{g}^{-1}$ dry weight. Total soluble phenols in fresh leaves were determined according to [24] and recorded as $\mathrm{mg} \mathrm{g}^{-1}$ dry weight. Free proline concentration ( $\mathrm{mg} \mathrm{g}^{-1}$ dry weight) was determined according to [28]. Nitrogen $\%$, and crude protein percentage was determined according to micro Kjeldahl as described by [24] phosphorus \% was determined according to [24] potassium was determined by Flame Photometer, Parkin-Elmer model 52 according to[19].

\section{Statistical analysis}

The experiment was in a complete randomized block design with 5 treatments and 6 pots as replicates for each treatment. Results were statistically analyzed using the L.S.D. a probability level of $5 \%$ for comparisons [29].

\section{Result}

\section{Vegetative parameters}

\section{Effect of propolis extract (PE) on growth characters}

Data presented in Tables 3, 4 indicated that propolis extract application method affected significantly growth parameters (plant height, number of leaves plant ${ }^{-1}$, total leaf area/plant and fresh and dry weight of leaves per plant). The results showed that using seed presoaked in PE caused significant increments in growth parameters during the two studied seasons. All tested growth parameters were gradually increased by increasing propolis extract levels up to $9000 \mathrm{mg} / \mathrm{L}$. The highest increase in yield represented in fresh weight of leaves was obtained by seeds soaking in propolis extract at $7000 \mathrm{mg} / \mathrm{L}$, with an increase by $(79.32$ and $86.06 \%)$ in the first and second seasons, respectively in compared with the control (seeds soaked in water). The same trend was also observed for plant height, number of leaves/plant, total leaf area /plant and dry weight of plant leaves especially with seed presoaking propolis extract at $7000 \mathrm{mg} / \mathrm{L}$ treatment in comparison to the control plants. Applying propolis extract at $7000 \mathrm{mg} / \mathrm{L}$ effectively alleviated the adverse effects of 
soil salinity on yield and its components. The highest increases were 59.78 and $74.04 \%$ for plant height, 52.70 and $60.00 \%$ for number of leaves/plant, 15.79 and $14.83 \%$ for total leaf area /plant and 79.32 and $86.06 \%$ for dry weight of plant leaves in the first and second seasons, respectively in compared with the control.

Table 3. Effect of propolis extract $(\mathrm{PE})$ as seed presoaking agent on plant height, number of leaves/plant, total leaf area and fresh weight of leaves/plant, of spinach plants in 2014 and 2015 seasons

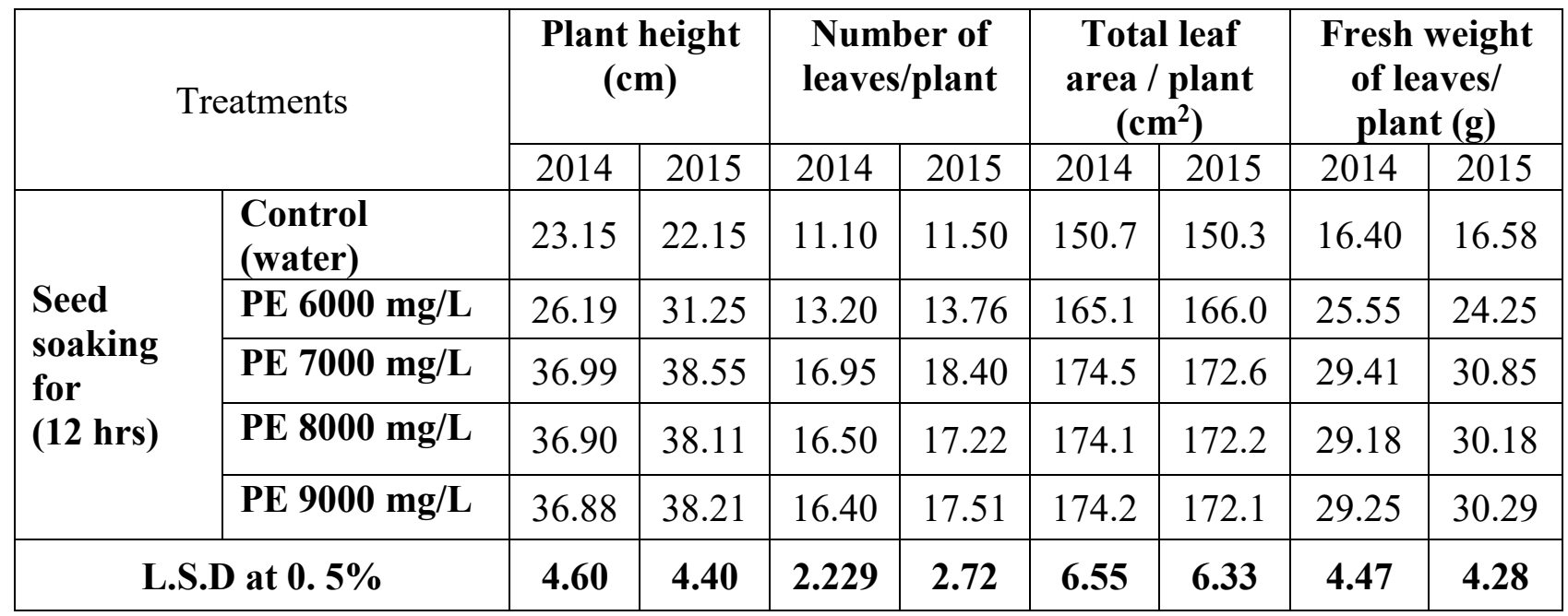

Effect of propolis extract (PE) on chemical constituents

\section{Leaf pigments concentration}

Data recorded in Tables 4, 5 clearly show that the concentration of leaf pigments (chlorophyll $\mathrm{a}, \mathrm{b}$, total caroteniods and anthocyanin) was significantly increased for seed soaking with propolis extract comparing with control plants.

The data also show that seed presoaking (PE) gave the best result in chlorophyll $a, b$, total caroteniods and anthocyanin of spinach plants. The maximum increase was obtained with (PE) at $7000 \mathrm{mg} / \mathrm{L}$ as seed presoaking which recorded 48.04 and $49.75 \%$ for chlorophyll a, 47.62 and $59.42 \%$ for chlorophyll b, 44.64 and $44.70 \%$ for total carotenoids, 84.84 and $87.94 \%$ for anthocyanin in the first and second seasons respectively compared to the control plants.

Table 4. Effect of propolis extract (PE) as seed presoaking agent on dry weight of leaves/plant, chlorophyll a \& b and total caroteniods concentration of spinach leaves in 2014 and 2015 seasons

\begin{tabular}{|c|c|c|c|c|c|c|c|c|c|}
\hline \multirow{2}{*}{\multicolumn{2}{|c|}{ Treatments }} & \multicolumn{2}{|c|}{$\begin{array}{l}\text { Leaf dry } \\
\text { weight } \\
\text { plant }^{-1}(g)\end{array}$} & \multicolumn{2}{|c|}{$\begin{array}{l}\text { Chlorophyll a } \\
\text { mg/100g F.W }\end{array}$} & \multicolumn{2}{|c|}{$\begin{array}{c}\text { Chlorophyll } \\
\text { b mg/100g } \\
\text { F.W }\end{array}$} & \multicolumn{2}{|c|}{$\begin{array}{c}\text { Total } \\
\text { caroteniods } \\
\text { mg100/g } \\
\text { F.W } \\
\end{array}$} \\
\hline & & 2014 & 2015 & 2014 & 2015 & 2014 & 2015 & 2014 & 2015 \\
\hline \multirow{5}{*}{$\begin{array}{l}\text { Seed } \\
\text { soaking } \\
\text { for } \\
(12 \text { hrs })\end{array}$} & $\begin{array}{l}\text { Control } \\
\text { (water) }\end{array}$ & 2.63 & 2.61 & 100.11 & 101.25 & 65.78 & 60.85 & 13.55 & 13.51 \\
\hline & PE $6000 \mathrm{mg} / \mathrm{L}$ & 3.87 & 3.84 & 120.80 & 120.60 & 85.07 & 84.18 & 16.18 & 16.25 \\
\hline & PE $7000 \mathrm{mg} / \mathrm{L}$ & 4.78 & 4.81 & 148.21 & 151.63 & 97.11 & 97.01 & 19.60 & 19.55 \\
\hline & PE $8000 \mathrm{mg} / \mathrm{L}$ & 4.29 & 4.27 & 147.14 & 150.75 & 96.89 & 96.78 & 19.01 & 19.02 \\
\hline & PE $9000 \mathrm{mg} / \mathrm{L}$ & 4.31 & 4.45 & 147.16 & 150.27 & 96.87 & 96.85 & 19.85 & 19.35 \\
\hline \multicolumn{2}{|c|}{ L.S.D at $0.5 \%$} & 0.63 & 0.60 & 16.02 & 16.28 & 10.54 & 10.22 & 4.25 & 4.28 \\
\hline
\end{tabular}

Total carbohydrates, total sugars and reducing sugars

Data recorded in Table 5 clearly show that in the two successive seasons application of propolis extract at the concentrations of $6000 \mathrm{mg} / \mathrm{L}$ up to $9000 \mathrm{mg} / \mathrm{L}$ significantly increased 
concentration of total carbohydrates, total sugars and reducing sugars as compared to the control plants. The best result for seed presoaking with (PE) was obtained with (PE) at $7000 \mathrm{mg} / \mathrm{L}$ which recorded 27.87 and $29.30 \%$ increase for total carbohydrate, 25.68 and $24.08 \%$ for total sugars and 54.64 and $51.86 \%$ for reducing sugar in the first and second seasons, respectively as compared to the control plants.

Table 5. Effect of propolis extract (PE) as seed presoaking agent on anthocyanin, total carbohydrates, total sugars and reducing sugars, of spinach leaves in 2014 and 2015 seasons

\begin{tabular}{|c|c|c|c|c|c|c|c|c|c|}
\hline \multirow{2}{*}{\multicolumn{2}{|c|}{ Treatments }} & \multicolumn{2}{|c|}{$\begin{array}{l}\text { Anthocyanin } \\
\text { concentration } \\
\text { mg/100g D.W }\end{array}$} & \multicolumn{2}{|c|}{$\begin{array}{c}\text { Total } \\
\text { carbohydrates } \\
\text { mg/g D.W }\end{array}$} & \multicolumn{2}{|c|}{$\begin{array}{c}\text { Total sugars } \\
\text { mg/g D.W }\end{array}$} & \multicolumn{2}{|c|}{$\begin{array}{l}\text { Reducing } \\
\text { sugars mg/g } \\
\text { D.W }\end{array}$} \\
\hline & & 2014 & 2015 & 2014 & 2015 & 2014 & 2015 & 2014 & 2015 \\
\hline \multirow{5}{*}{$\begin{array}{l}\text { Seed } \\
\text { soaking } \\
\text { for } \\
(12 \mathrm{hrs})\end{array}$} & $\begin{array}{l}\text { Control } \\
\text { (water) }\end{array}$ & 26.66 & 26.38 & 190.15 & 189.28 & 77.99 & 79.04 & 29.15 & 29.77 \\
\hline & PE $6000 \mathrm{mg} / \mathrm{L}$ & 37.15 & 38.21 & 216.99 & 219.55 & 89.25 & & 32.58 & 35.74 \\
\hline & PE $7000 \mathrm{mg} / \mathrm{L}$ & 49.28 & 49.58 & 243.25 & 244.74 & 98.02 & 98.08 & 45.08 & 45.21 \\
\hline & PE $8000 \mathrm{mg} / \mathrm{L}$ & 49.02 & 49.03 & 241.15 & 243.04 & 97.50 & 97.89 & 44.78 & 44.85 \\
\hline & PE $9000 \mathrm{mg} / \mathrm{L}$ & 49.17 & 49.28 & 241.47 & 243.13 & 97.75 & 97.40 & 44.25 & 44.72 \\
\hline \multicolumn{2}{|c|}{ L.S.D at $0.5 \%$} & 7.55 & 7.61 & 22.03 & 22.09 & 10.10 & 10.10 & 6.08 & 6.12 \\
\hline
\end{tabular}

Total free amino acids, total indoles, total phenols, free proline and crud protein

Data recorded in Tables 6, 7 clearly show that in the two studied seasons, all propolis extract treatments significantly increased total free amino acids, total indoles, total phenols, free proline and crud protein in spinach leaves in comparing with the control plants. The maximum increase was obtained when $7000 \mathrm{mg} / \mathrm{L}$ of PE was used in the form of seed pre-soaking agent which resulted in 70.30 and $66.53 \%$ for total free amino acids, 79.15 and $73.71 \%$ for total indoles, 73.94 and $75.15 \%$ increase for total phenols, 15.20 and $14.36 \%$ for free proline and 50.00 and $48.35 \%$ for crud protein in the first and second seasons, respectively compared with the control plants.

Table 6. Effect of propolis extract (PE) as seed presoaking agent on total free amino acids, total indoles, total phenols and free proline of spinach leaves in 2014 and 2015 seasons

\begin{tabular}{|c|c|c|c|c|c|c|c|c|c|}
\hline \multirow{2}{*}{\multicolumn{2}{|c|}{ Treatments }} & \multicolumn{2}{|c|}{$\begin{array}{c}\text { Total free } \\
\text { amino acid } \\
\text { mg/g D.W }\end{array}$} & \multicolumn{2}{|c|}{$\begin{array}{l}\text { Total indoles } \\
\mathrm{mg} / \mathrm{g} \mathrm{D.W}\end{array}$} & \multicolumn{2}{|c|}{$\begin{array}{c}\text { Total phenols } \\
\text { mg/g D.W }\end{array}$} & \multicolumn{2}{|c|}{$\begin{array}{c}\text { Free proline } \\
\text { mg/g D.W }\end{array}$} \\
\hline & & 2014 & 2015 & 2014 & 2015 & 2014 & 2015 & 2014 & 2015 \\
\hline \multirow{5}{*}{$\begin{array}{l}\text { Seed } \\
\text { soaking } \\
\text { for } \\
(12 \mathrm{hrs})\end{array}$} & $\begin{array}{l}\text { Control } \\
\text { (water) }\end{array}$ & 17.21 & 17.66 & 7.58 & 7.61 & 7.79 & 7.85 & 1.71 & 1.74 \\
\hline & PE $6000 \mathrm{~g} / \mathrm{L}$ & 19.98 & 20.20 & 9.99 & 9.89 & 10.22 & 10.42 & 1.80 & 1.80 \\
\hline & PE 7000 g/L & 29.31 & 29.41 & 13.58 & 13.22 & 13.55 & 13.75 & 1.97 & 1.99 \\
\hline & PE $8000 \mathrm{~g} / \mathrm{L}$ & 28.15 & 28.17 & 12.96 & 12.98 & 13.21 & 13.11 & 1.90 & 1.91 \\
\hline & PE 9000 g/ & 28.25 & 28.55 & 12.96 & 12.99 & 13.08 & 13.23 & 1.92 & 1.95 \\
\hline \multicolumn{2}{|c|}{ L.S.D at $0.5 \%$} & 2.61 & 2.59 & 2.06 & 2.08 & 2.57 & 2.69 & 0.04 & 0.03 \\
\hline
\end{tabular}

Nitrogen, phosphorus and potassium concentrations

Data in both two studied seasons presented in Table 7 indicate that leaves of spinach plants contained a high concentration of nitrogen; phosphorus and potassium due to propolis extract applications condition comparing to control plants. Moreover, the chemical constituents were significantly increased with increasing propolis extract rates. The maximum increase was obtained from the application of seeds presoaking propolis extract at the rate of $7000 \mathrm{mg} / \mathrm{L}$ were 50.00 and 
$48.35 \%$ for nitrogen, 48.48 and $48.48 \%$ for phosphorous and 24.34 and $25.33 \%$ for potassium in both seasons respectively compared to the control plants.

Table 7. Effect of propolis extract (PE) as seed presoaking agent on crud protein, nitrogen, phosphorous and potassium of spinach seeds in 2014 and 2015 seasons

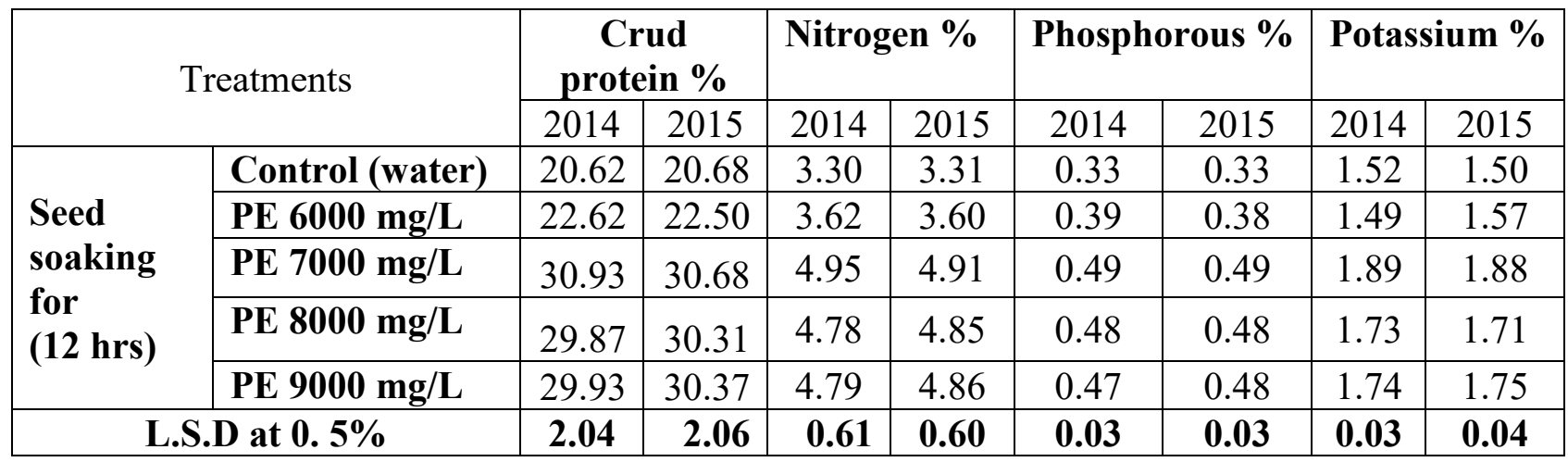

\section{Chemical composition of seeds after presoaking}

Effect of (PE) seed presoaking on seed content from total carbohydrate, total sugars and reducing sugars

Data presented in Table 8 indicated that soaking spinach seeds in propolis extract at all the concentration significantly decreased total carbohydrate while produced a significant increase in total and reducing sugars compared to untreated seeds or soaking in water for the same soaking periods. The highest increase in total sugars was (48.56 and 50.05\%) in the first and second season respectively by $\mathrm{PE}$ at $7000 \mathrm{mg} / \mathrm{L}$ as compared to seeds soaking in water. The same trend was also observed for reducing sugars. The increase was $(72.25$ and $74.06 \%)$ at $7000 \mathrm{mg} / \mathrm{L} \mathrm{PE}$ soaking in the first and second season respectively as compared to soaked with seeds in water.

Table 8. Effect of propolis extract (PE) as seed presoaking agent on total carbohydrates, total sugars and reducing sugars of spinach seeds in 2014 and 2015 seasons

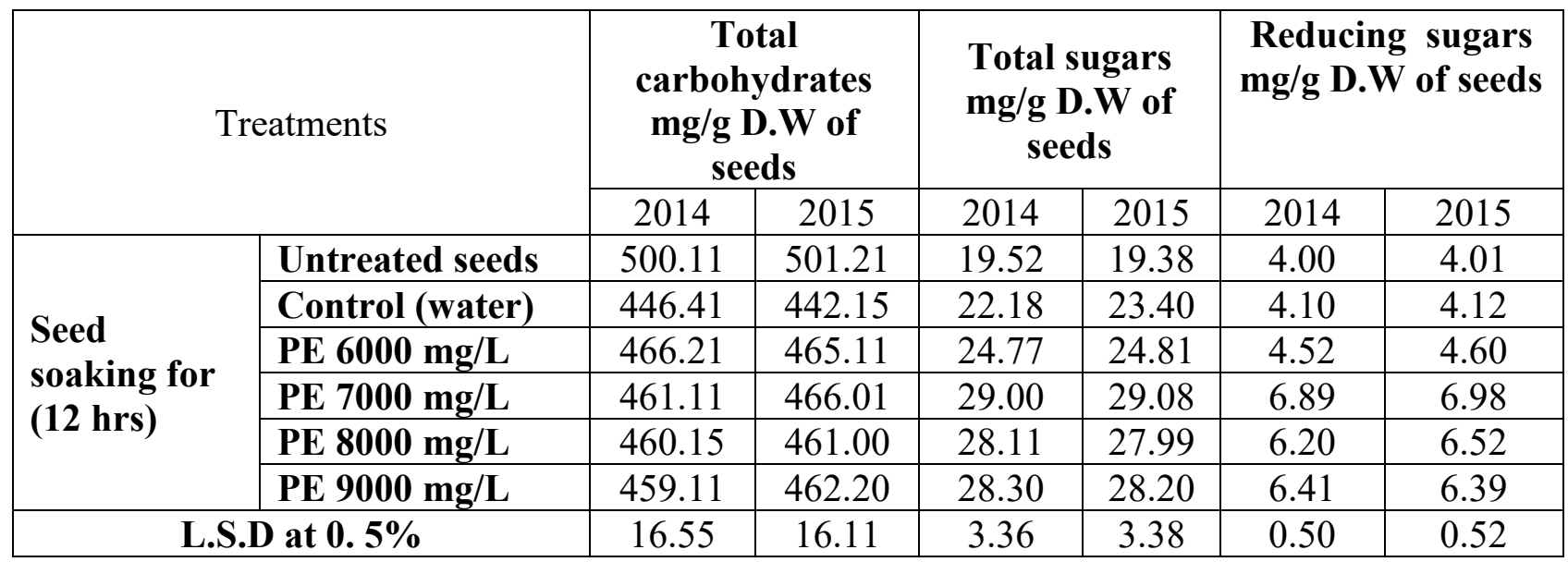

Effect of (PE) seed presoaking on seed content from total free amino acids, total indoles and total soluble phenols

It is clear from data showed in Table 9 that the concentration of total free amino acid, total indoles and total soluble phenols of tested seeds was increased significantly by the PE soaking at all concentration when compared to untreated seeds or soaking in water. The best result was obtained when propolis extract at $7000 \mathrm{mg} / \mathrm{L}$ was used. The highest increase was recorded 91.44 and $88.43 \%$ for total free amino acids, 78.19 and $77.77 \%$ for total indoles and 71.32 and $73.00 \%$ for total soluble phenols in the first and second season respectively as compared to seeds soaking in water. 
Table 9. Effect of propolis extract (PE) as seed presoaking agent on total free amino acids, total indoles and total phenols of spinach seeds in 2014 and 2015 seasons

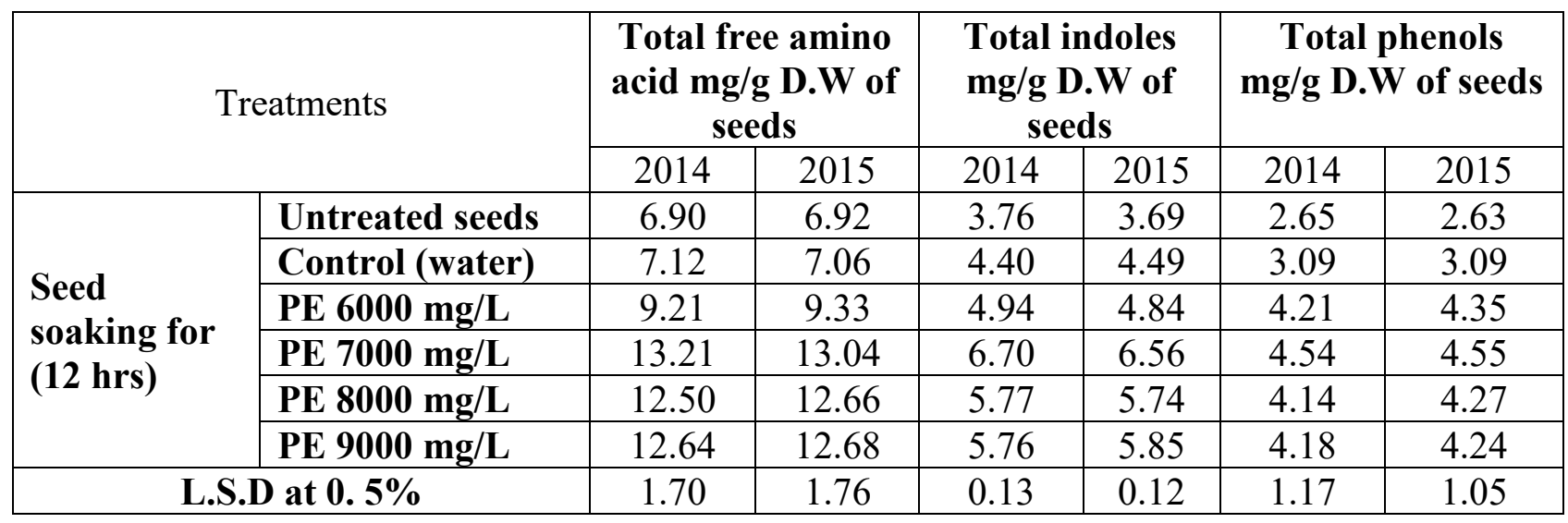

\section{Discussion}

It is clear with the knowledge that soil salinity reduces the various metabolic processes that are liable for traditional plant growth. The adverse result on the syntheses of chlorophyll $a, b$, carotenoids, anthocyanin, sugars, total free amino acids, proline, $\mathrm{N}$, crude protein and plant auxin concentration that occurred as a result of soil salt stress was reduced by treating the plants with propolis extract. In this connection, Nikolaev [30] and Salama et al [31] reported that the increment in leaf pigments concentration of propolis extract-treated plants might well be attributed to the rise in their hormones, and /or that propolis extract enhances mineral absorption, i.e. ( $\mathrm{Fe}$ and $\mathrm{Mn}$ ) required for chlorophyll synthesis, since that these parts are found among mineral composition of propolis extract. [32] reported that the hyperbolic level of anthocyanin indicates an index for a decent mechanism of plant resistance towards the changes within the environmental conditions. The rise in total sugars concentration could also be attributed to the sweetening of photosynthesis by the impact of propolis extract dilated stating from its impact on seed presoaking until completely different stages of plant growth. On the opposite hand propolis extract would possibly overcome the obligatory NaCl-salt stress via accumulation of sugars. So the increase in total sugars concentration might plays a very important role in adjusting osmotic potential of the protoplasm, a conclusion that is in accordance with results obtained by $[33,15]$. As well as propolis extract contain some matter like terpenoids $[21,34]$ from that $\mathrm{GA}_{3}$ is synthesized. The rise in total free amino acids and free proline concentrations of propolis extract-treated plants could also be appreciated for that, these plants might show higher degradation rate of proteins and/ or accumulation of many amino acids ensuing from the inhibition of their incorporation into proteins. The increment in protein concentration in propolis extract-treated plants can be attributed to that, propolis extract contains some B- group vitamins [30]. Since Tayeb [35] recorded that, vitamins of B- group acting as coenzymes, are possess some freelance roles within the biochemical processes of plants. Moreover, Rao et al., [36] proved associated increased protein synthesis with increasing in B- group vitamins accumulation might well be through functioning at the interpretation level of protein synthesis. The increment in total soluble phenols concentration in propolis extract-treated plants may well be attributed to the increment in their total sugars concentration, and/or is also thanks to the rise within the metabolic activity of those plants to synthesize shikimic acid [37]. On the opposite hand the rise in total soluble phenols synthesis in propolis extract-treated plants could indicate that, propolis extract would possibly overcome the obligatory NaCl-salt stress via accumulation of the part that constitutes with different elements (i.e. sugars, proline and total free amino acids) cellular solutes[38] for sustenance of cells state resulting in maintenance of metabolic activities in these plants. Moreover, the increment in total indoles concentration of leaves of propolis extract- treated plants is also attributed to the rise in their total free amino acids that embrace tryptophan amino acid as a precursor of IAA as shown from results of this study. The rise in macro parts in propolis extract-treated plants is also because of the presents of these parts in propolis extract. In this respect, 
Walker and Crane [21] listed 149 compounds and twenty two minerals from totally different samples of propolis. Likewise as propolis extract contain many helpful mineral elements (i.e. K, $\mathrm{Mg}, \mathrm{Ca}, \mathrm{Cu}, \mathrm{Zn}, \mathrm{Mn}$, and $\mathrm{Fe}$ ) which might compensate presoaked seeds and their developed plants under the conditions of shortage of those mineral elements in carbonate soil, and /or that propolis extract could form a coat round the surface of propolis extract-presoaked seeds and make-do as a block for injurious cations and anions of (free radical) carbonate soil [34, 15]. An increasing in the measured growth characters (plant height etc.) of propolis extract-treated plants could also be attributed to the rise in indoles in these plants (Tables 5 and 6) that might induce increase in cell division and enlargement [39, 40]. Also, propolis extract contains some compounds that enhance or alter plant metabolism resulting in the rise within the leaf area [14], e.g. terpenoids which can induce the vigorous growth and /or enhance plant metabolism resulting in the rise in each fresh and dry weight [34]. Therefore, propolis extract exhibits compensatory result against the hurtful result of NaCl-salinity. This suggestion could also be because of that, propolis extract contains terpenoids [21] that have the potential to stimulate plant growth, therefore provide the plants a lucid vigor in growth to resist the adverse impact of $\mathrm{NaCl}$-salinity. The positive impact of propolis extract on seed constituents of the soluble substances before planting could also be attributed to the presence of sugars among the constants of propolis extract [21] and or the rise in $œ$-amylase activity. The rise in total free amino acids could also be due to the presence of amino acids together with tryptophan among the parts of propolis extract [21] and the, therefore, the vital increase in total free amino acids concentration could also be thanks to that, propolis extract inhibits amino acid incorporation into proteins. Furthermore, the rise in total phenols could also be attributed to the rise in metabolic activity of those tested seeds to synthesize shikimic acid [37] iatrogenic by the propolis extract and /or the rise in sugars concentration in propolis extract treated seeds. These results are typically fully in agreement with those obtained by several investigators, [7, 14-17] on different plants.

\section{Conclusions}

Propolis extract as seed soaking application to salt-stressed plants has been shown to reinforce plant salt stress defense responses, to act directly and/or indirectly at rising total plant performances (growth and yields) under salt stress. Thus, propolis might offer an efficient strategy to alleviate the adverse effects of salt stress through inflated N-utilization, leading to less harm to spinach growth and its protection from dangerous effects of salt stress. Therefore, propolis extract might act to alleviate the severity of salt stress on spinach plants grown on saline soils.

\section{Conflict of Interest}

The authors declare that there is no conflict of interest.

\section{References}

[1] N.R. Galla, P.R. Pamidighantam, B. Karakala, Nutritional, textural and sensory quality of biscuits supplemented with spinach (Spinacia oleracea L.), International Journal of Gastronomy \& Food Science. 7 (2016) 20-26.

[2] A. Altemimi, R. Choudhary, D.G. Watson, Effects of ultrasonic treatments on the polyphenol and antioxidant content of spinach extracts, Ultrasonics Sonochemistry. 24(25) (2014) 247-255.

[3] A. KılıçKan, N. Üçer, I. YalçIn, Some physical properties of spinach (Spinacia oleracea L.) seed, African Journal of Biotechnology. 9(5) (2010) 648-655.

[4] S.A. Mohamed, R.A. Medani, M.A. EL-Yazal, The effect of nitrogen and phosphorus fertilization as foliar application on botanical, characters of spinach (Spinacia oleracaea L.) plants grown under calcareous saline soil conditions, Fac. of Agric., Fayoum Univ., 16-18 January, (2006), pp. 67-83. 
[5] S. Ors, D.L.Suarez, Salt tolerance of spinach as related to seasonal climate, Hort. Sci. (Prague) 43(1) (2016) 33-41.

[6] D. Mohamed et al., $\mathrm{Na} \mathrm{Cl}$ stress effects on enzymes involved in nitrogen assimilation pathway in tomato (Lycopersicon esculentum L.) seedlings, J. Plant Physiol. 163(12) (2005) 1247-1258.

[7] W.M. Semida, M.M. Rady, Presoaking application of propolis and maize grain extracts alleviates salinity stress in common bean (Phaseolus vulgaris L.), Scientia Horticulturae. 168(2014) 210-217.

[8] A.I. Rushdi et al., Characteristics and chemical compositions of propolis from Ethiopia, Springer Plus. 3 (2014) 253.

[9] S. Ramnath, S. Venkataramegowda, C. Singh, Chemical Composition of Bee Propolis Collected from Different Regions in India by GCMS Analysis, International Journal of Pharmacognosy and Phytochemistry. 30(1) (2015) 1319-1328.

[10] B.A.S. Machado et al., Chemical composition and biological activity of extracts obtained by supercritical extraction and ethanolic extraction of brown, green and red propolis derived from different geographic regions in Brazil, PLoS One. 11(1) (2016) e0145954

[11] A.M. Saad et al., Chemical constituents and biological activities of different solvent extracts of Prosopis farcta growing in Egypt, Journal of Pharmacognosy and Phytotherapy. 9(5) (2017) 67-76.

[12] A.A. Al-Ghamdi et al., Chemical compositions and characteristics of organic compounds in propolis from Yemen, Saudi Journal of Biological Sciences. 24(5) (2017) 1094-1103.

[13] H.M. Fathy et al., Chemical and biological diversity of propolis samples from Bulgaria, Libya and Egypt, Journal of Apitherapy. 3(2) (2018) 17-23.

[14] E.M. El-Assiuty et al., Propolis in controlling sorghum downy mildew and stimulating plant growth of maize, Egypt J. Appl. Sci. 15(12) (2000) 45-54.

[15] M.M. Rady, Response of propolis extract-presoaking seeds of some crops to salt tolerance under different soil conditions, Ph.D. Thesis Fac. Agric. Fayoum, Cairo Univ., 2002.

[16] E.M.A. Noweer, M. G. Dawood, Efficiency of propolis extract on faba bean plants and its role against nematode infection, Comm. Appl. Sci, Ghent University 74(2) (2009) 593-603.

[17] A. Abou-Sreea, S. Mahfouz, R. M. Zewainy, Effectiveness of propolis aqueous extract on chemical constituents of Calendula Plants, International Journal of Pharmaceutical and Clinical Research. 9 (2) (2017) 137-143.

[18] A. Klute, Methods of Soil Analysis Part 1, Physical and Meneralogical Methods, $2^{\text {nd }}$ Edition. American Society of Agronomy, Medison, Wisconsin, U.S.A., 1986.

[19] A.I. Page, R.H. Miller, D. Keeny, Methods of Soil Analysis. Part 2: Chemical and Microbiological Properties. $2^{\text {nd }}$ Ed. (1982). Amer. Soc. Agron., Madison, Wisconsin, USA.

[20] L. Vechet, Effect of propolis on some species of microorganisms and moulds, In a remarkable hive product. Propolis 1978, pp.53-59. Bucharest, Romania: Apimondia Publishing house.

[21] P. Walker, E. Crane, Constituents of propolis, Apidologie. 18(4) (1987) 327-334.

[22] A.R. Wellburn, H. Lichtenthaler, Formulae and program to determine total caroteniods and chlorophyll $\mathrm{a}$ and $\mathrm{b}$ of leaf extracts different solvents. In advances in photosynthesis Research (Sybesma C.Ed.) Vol. II, 1984, pp. 9-12. Mortinus Njihoff Dr.W. Junk publishers, The Hague.

[23] D. Herbert, P.J. Phipps, R.F. Strange, Determination of total carbohydrates. Methods in Microbian. 5 (B) (1971) 209-244.

[24] A.O.A.C., Official Methods of Analysis of the Association of Official Agricultural Chemists, Sixteenth ed. (1995), Washington D.C., USA. 
[25] R. E. Hoagland, Effect of glycophosphate on metabolism of phenolic compounds. VI. Effect of glyphosime and glyphosate metabolites on phenylalanine ammonia lyase activity, growth, protein and chlorophyll an anthocyanin levels in soybean seedlings, Weed Sci. 28 (1980) 393.

[26] J. Jayarman, Laboratory Manual in Biochemistry. Willey Eastren limited, New York,1981, pp. 61-73.

[27] P. Larson et al., On the biogenesis of some indole compounds in Acetobacter xylimum, Physiol. Plant. (15) (1962) 552-565.

[28] L.S. Batcs, R.P. Waldren, I.D. Tearc, Rapid determination of free proline for water stress studies, Plant and Soil. 39 (1973) 205-207.

[29] K.A. Gomez, A.A. Gomez, Statistical Analysis Procedure of Agricultural Research, John Wiley and Sons, New York, 1983, pp. 25-30.

[30] A. B. Nikolaev, Defining the bee town, In A remarkable hive product: Propolis. Scientific data and suggestions concerning its composition, properties and possible use in therapeutics. Apimondia Standing Commission on Beekeeping Technology and Equipment, Bucharest (1978). ( c.f. A.G. Hegazi, Propolis an overview, International Symposium on Apitherapy, Natoinal Research Center, Cairo, Egypt, March 8-9 ${ }^{\text {th }}, 1997$.

[31] M.I. Salama et al., Leaf pigment and nutrient element content of Roumi Red grape nurslings as affected by salinity and some growth regulators, J. Agric. Rec. Tanta Univ. 18(2) (1992) 382-391.

[32] H. M. El-Saht, Metribuzin herbicide induced a defense mechanism in normal and NaClstressed castor bean and maize plants, Egypt. J. Hort. 28(2) (2001) 277-290.

[33] T. J. Flowers, P.P. Troke, A.R.Yeo, The mechanism of salt tolerance in halophytes, Ann. Rev. Plant Physiol. 28 (1977) 89-121.

[34] V.S. Bankova, S.L. De Castro, M.C. Marucci, Propolis: recent advances in chemistry and plant origin, Apidologie. 31 (2000) 3-15.

[35] M.A. EL-Tayeb, Effect of thiamin seed presoaking on the physiology of Sorghum bicolor L. plants grown under salinity stress, Egypt, J. Bot. 35(2) (1995) 201-214.

[36] P. Gopala Rao, C. Damodara Reddy, J.K. Ramaiah, Effect of B vitamins on the protein component of cluster bean Cyamopsis tetragonoloba L., Taub, Ann. Bot. 59 (1987) 281- 292.

[37] R.M. Devlin, F.H. Witham, Plant physiology. $4^{\text {th }}$ Ed. CBS Publishers and Distributors, 485 Jain Bhawan, Bhola Nath Nagar, Shahdara, Delhi-110 032 (India), 1986, p. 443.

[38] N. Das, M. Misra, A.N. Misra, Sodium chloride salt stress induced metabolic change in callus cultures of Pearl Millet (Pennissetum americanum L. Leek.) free solute accumulation, J. Plant Physiol. 137 (1990) 244-246.

[39] S. Weidner, Role of gibberellins and cytokinins in regulation of germination during development and ripening of Triticale caryopes L., Acta Societatis, Botanicorum Poloninae. 53(2) (1984) 257-270.

[40] L. Zhaoliang et al., The effect of paclobutrazol on plant histology of some crops, Acta Agric Shanghai. 11 (1995) 43-47. 